case report

\title{
Pituitary metastasis of renal cell carcinoma: a case report
}

\author{
Vesna Bišof ${ }^{1}$, Antonio Jureticí ${ }^{1}$, Nera Šarić ${ }^{1}$, Ante Melada ${ }^{2}$, \\ Zdravko Perkovic ${ }^{3}$, Marko Radoš ${ }^{4}$, Ranka Padovan Štern ${ }^{4}$ \\ ${ }^{1}$ Department of Oncology, ${ }^{2}$ Department of Neurosurgery, ${ }^{3}$ Department of Endocrinology, \\ ${ }^{4}$ Clinical Institute for Diagnostic and Interventional Radiology, \\ University Hospital Centre "Zagreb", Zagreb, Croatia
}

Background. Solitary metastasis of renal cell carcinoma in the pituitary gland is extremely rare and only in $7 \%$ of cases it is symptomatic.

Case report. We report the case of a 52 year old man presenting with visual disturbance and headache after three years of treatment due to the metastatic renal cell carcinoma. Magnetic resonance imaging (MRI) showed tumour mass in supraselar region compressing optic chiasm with no other brain metastatic lesions. The trans-sphenoidal reduction of the tumour was performed. Pathology and imunohistology revealed metastasis of clear cell renal carcinoma.

Conclusions. This is the $25^{\text {th }}$ case of symptomatic pituitary metastases of renal cell carcinoma reported in literature.

Key words: pituitary gland; renal cell carcinoma; metastasis

\section{Introduction}

Renal cell carcinoma is the most common primary tumour of the kidney accounting $1-3 \%$ of all adult malignancies. ${ }^{1}$ Although brain is the fourth most common site of metastasis after lung, bone and liver with approximately $5 \% 1$, solitary metastasis of renal cell carcinoma in the pituitary gland

Received 14 October 2008

Accepted 28 October 2008

Correspondence to: Vesna Bišof, MD, Department of Oncology, University Hospital Centre "Zagreb", Kišpatićeva 12, Zagreb, Croatia. Phone: +385 12388 035; Fax: +385 12388 583; E-mail: vesna.bisof@zg.t-com.hr is extremely rare. ${ }^{1-6}$ The frequency of pituitary metastases from systemic malignant tumours ranged from $1 \%$ to $25 \%$ at autopsy. ${ }^{7}$ Only $7 \%$ of pituitary metastases are symptomatic. ${ }^{2}$ Pituitary metastases occur usually in patients with highly disseminated disease. Breast and lung cancer are the most common diseases that metastasize to the pituitary gland. ${ }^{2,6}$

\section{Case report}

We present the case of a patient diagnosed with a pituitary gland metastatic renal cell carcinoma after three years of treatment due 


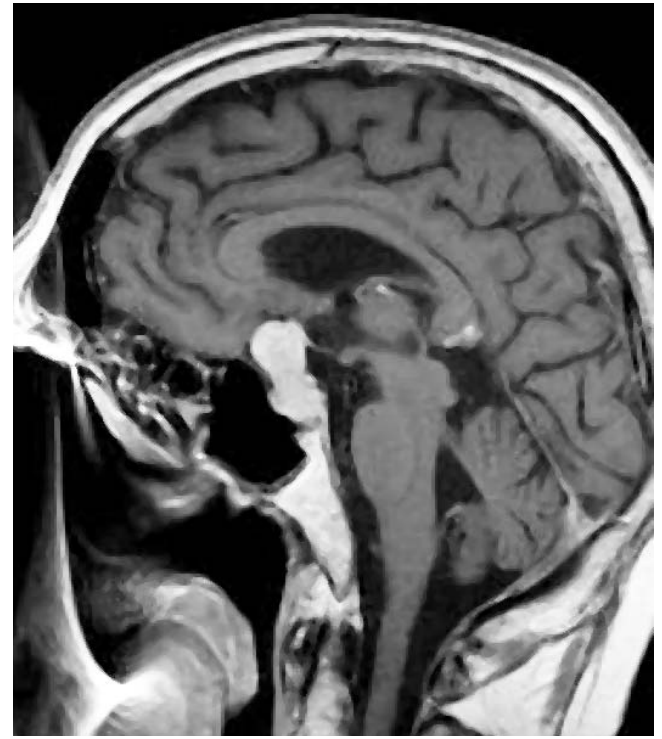

Figure 1a. Tumour mass in supraselar region presented by magnetic resonance imaging (MRI), sagittal image.

to the metastatic disease. In August 2003, a 49 year old man presented with tumour of the lower part of the left kidney. Left nephrectomy was performed. Pathology confirmed clear cell carcinoma, tumour stage T3bN0M0. During his first postoperative visit to the oncological department multiple bilateral lung metastases smaller than $1 \mathrm{~cm}$ in diameter were found along with osteolysis of the posterior part of the forth right rib. Patient ECOG score was 0. Since interferon and interleukin-2 were not registered for the treatment of metastatic renal cell carcinoma in Croatia, his treatment was started with chemotherapy - vinblastin $6 \mathrm{mg} / \mathrm{m}^{2}$ every two weeks from December 2003 until June 2004.

Control examinations performed during the treatment revealed a stable disease. However, on control computed tomography (CT) in September 2004 the progression of the forth posterior rib lesion measuring now $3.5 \times 6.8 \mathrm{~cm}$ in diameter with protrusion in intratoracic space was found. Lung metastatic disease was stable. There was no sign

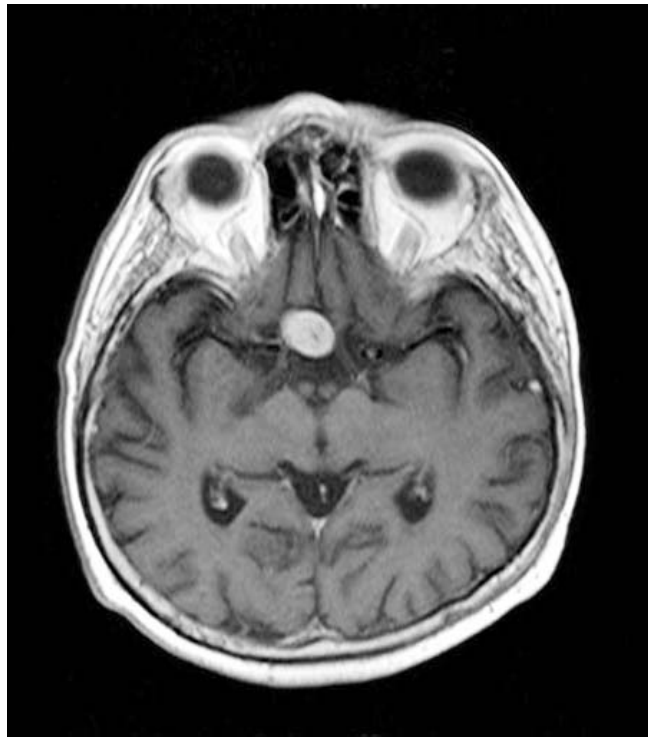

Figure $\mathbf{1 b}$. Tumor mass in supraselar region presented by magnetic resonance imaging (MRI), axial image.

of other metastatic site. The palliative radiotherapy treatment to the progressed lesion of the forth posterior rib was performed; dose $30 \mathrm{~Gy}$ in 10 fractions. The second line chemotherapy was lomustin (CCNU) 160 mg every 5 weeks, 7 cycles, from October 2004 until May 2005.

CT scan done in May 2005 revealed the progression of lung metastases i.e. enlargement in size and number of lung lesions. On the contrary, the lesion of the forth rib was smaller than on the previous CT scan. Since June 2005 until September 2005 the patient was treated with 5-fluorouracil (5-FU) once a week and with an interferon A $2 \alpha 3$ mil IU sc. three times a week (purchased by the patient). Due to the fatigue of the patient and enlargement of the fourth rib lesion, along with stable disease of other metastatic lung lesions, it was decided to perform reirradiation to enlarged lesion, total dose 30 Gy in 10 fractions. From December 2005 until April 2006, 5 - FU and interferon A $2 \alpha$ therapy was continued. Due to the progression of the lung lesions from April 2006 un- 
Table 1. Reported cases of pituitary metastasis from renal cell carcinoma

\begin{tabular}{|c|c|c|c|c|c|}
\hline Author & Age/Sex & $\begin{array}{l}\text { Interval from } \\
\text { primary } \\
\text { diagnosis } \\
\text { to pituitary } \\
\text { metastasis }\end{array}$ & $\begin{array}{l}\text { Endocrinological } \\
\text { finding }\end{array}$ & $\begin{array}{l}\text { Visual } \\
\text { involvement }\end{array}$ & Treatment \\
\hline Anniko et al. $(1981)^{8}$ & $59 / \mathrm{M}$ & 9 years & hypopituitarism & yes & surgery \\
\hline Bounaguidi et al. $(1983)^{9}$ & $53 / \mathrm{M}$ & 0 year & $\begin{array}{l}\text { hypopituitarism, } \\
\text { diabetes insipidus }\end{array}$ & yes & $\begin{array}{l}\text { surgery, } \\
\text { RT to pituitary fossa }\end{array}$ \\
\hline James et al. $(1984)^{3}$ & $75 / \mathrm{M}$ & 9 years & normal & yes & surgery \\
\hline Eick et el. $(1985)^{10}$ & $66 / \mathrm{M}$ & 0 year & hypopituitarism & no & $\begin{array}{l}\text { surgery, RT to pituitary } \\
\text { fossa and whole brain }\end{array}$ \\
\hline Horikoshi et al. (1988) ${ }^{11}$ & $51 / \mathrm{M}$ & 0 year & hypopituitarism & yes & $\begin{array}{l}\text { surgery, } \\
\text { RT to pituitary fossa }\end{array}$ \\
\hline McCormic et al. $(1989)^{5}$ & $35 / \mathrm{F}$ & 0 year & hypopituitarism & yes & $\begin{array}{l}\text { surgery, RT to sella and } \\
\text { parasellar region }\end{array}$ \\
\hline Nishio et al. $(1992)^{12}$ & $63 / \mathrm{F}$ & 4 years & hypopituitarism & yes & $\begin{array}{l}\text { surgery, } \\
\text { RT to pituitary fossa }\end{array}$ \\
\hline Koshiyama et al. (1992) & $57 / \mathrm{M}$ & 0 year & hypopituitarism & yes & $\begin{array}{l}\text { surgery, } \\
\text { RT to pituitary fossa }\end{array}$ \\
\hline Weiss et al. $(1993)^{13}$ & $59 / \mathrm{M}$ & 0 year & hypopituitarism & yes & $\begin{array}{l}\text { surgery, } \\
\text { RT to pituitary fossa }\end{array}$ \\
\hline Uchino et al. $(1996)^{14}$ & $63 / \mathrm{F}$ & 4 year & NA & NA & surgery \\
\hline Beckett et al. $(1998)^{15}$ & $56 / \mathrm{M}$ & 0 year & hypopituitarism & no & $\begin{array}{l}\text { surgery, RT to pituitary } \\
\text { fossa, interferon- } \alpha\end{array}$ \\
\hline \multirow{2}{*}{$\begin{array}{l}\text { Marar et al. } \\
-2 \text { cases }(1998)^{16}\end{array}$} & $54 / \mathrm{M}$ & 3 years & hypopituitarism & yes & surgery \\
\hline & $73 / \mathrm{M}$ & 8 years & hypopituitarism & no & surgery \\
\hline Weber et al. $(2003)^{17}$ & $62 / \mathrm{M}$ & 4 years & diabetes insipidus & yes & surgery \\
\hline Basaria et al. $(2004)^{18}$ & $77 / \mathrm{F}$ & 3 months & hypopituitarism & yes & surgery, stereotactic RT \\
\hline Yokoyama et al. $(2004)^{1}$ & $63 / \mathrm{M}$ & 8 years & $\begin{array}{l}\text { hypopituitarism, } \\
\text { diabetes insipidus }\end{array}$ & yes & stereotactic RT \\
\hline Pallud et al. (2005) ${ }^{19}$ & $70 / \mathrm{M}$ & 6 years & NA & yes & $\begin{array}{l}\text { surgery, } \\
\text { RT to pituitary fossa }\end{array}$ \\
\hline Liu et al. $(2005)^{7}$ & $54 / \mathrm{M}$ & NA & hypopituitarism & yes & $\begin{array}{l}\text { surgery, RT to pituitary } \\
\text { fossa, interferon- } \alpha\end{array}$ \\
\hline \multirow[t]{5}{*}{$\begin{array}{l}\text { Gopan et al. (2007) } \\
\text { - five cases }\end{array}$} & $67 / \mathrm{M}$ & 27 years & $\begin{array}{l}\text { hypopituitarism, } \\
\text { diabetes insipidus }\end{array}$ & yes & $\begin{array}{l}\text { surgery, whole brain } \\
\text { RT with boost to the } \\
\text { pituitary fossa }\end{array}$ \\
\hline & $51 / \mathrm{M}$ & 12 years & hypopituitarism & yes & $\begin{array}{l}\text { surgery, whole brain } \\
\text { RT, interferon- } \alpha \text {, } \\
\text { thalidomide, sunitinib }\end{array}$ \\
\hline & $53 / \mathrm{M}$ & 0 year & $\begin{array}{l}\text { hypopituitarism, } \\
\text { diabetes insipidus }\end{array}$ & yes & $\begin{array}{l}\text { surgery, } \\
\text { RT to the sella }\end{array}$ \\
\hline & $67 / \mathrm{F}$ & 11 years & hypopituitarism & no & $\begin{array}{l}\text { stereotactic RT, } \\
\text { sorafenib }\end{array}$ \\
\hline & $61 / \mathrm{F}$ & 1 year & hypopituitarism & no & $\begin{array}{l}\text { stereotactic RT, AG } \\
013736^{*}\end{array}$ \\
\hline $\begin{array}{l}\text { Bisof et al. }(2008) \\
- \text { this report }\end{array}$ & $49 / \mathrm{M}$ & 3 years & hypopituitarism & yes & surgery, whole brain RT \\
\hline
\end{tabular}

* phase II clinical trial with tyrosine kinase inhibitor AG-013736 


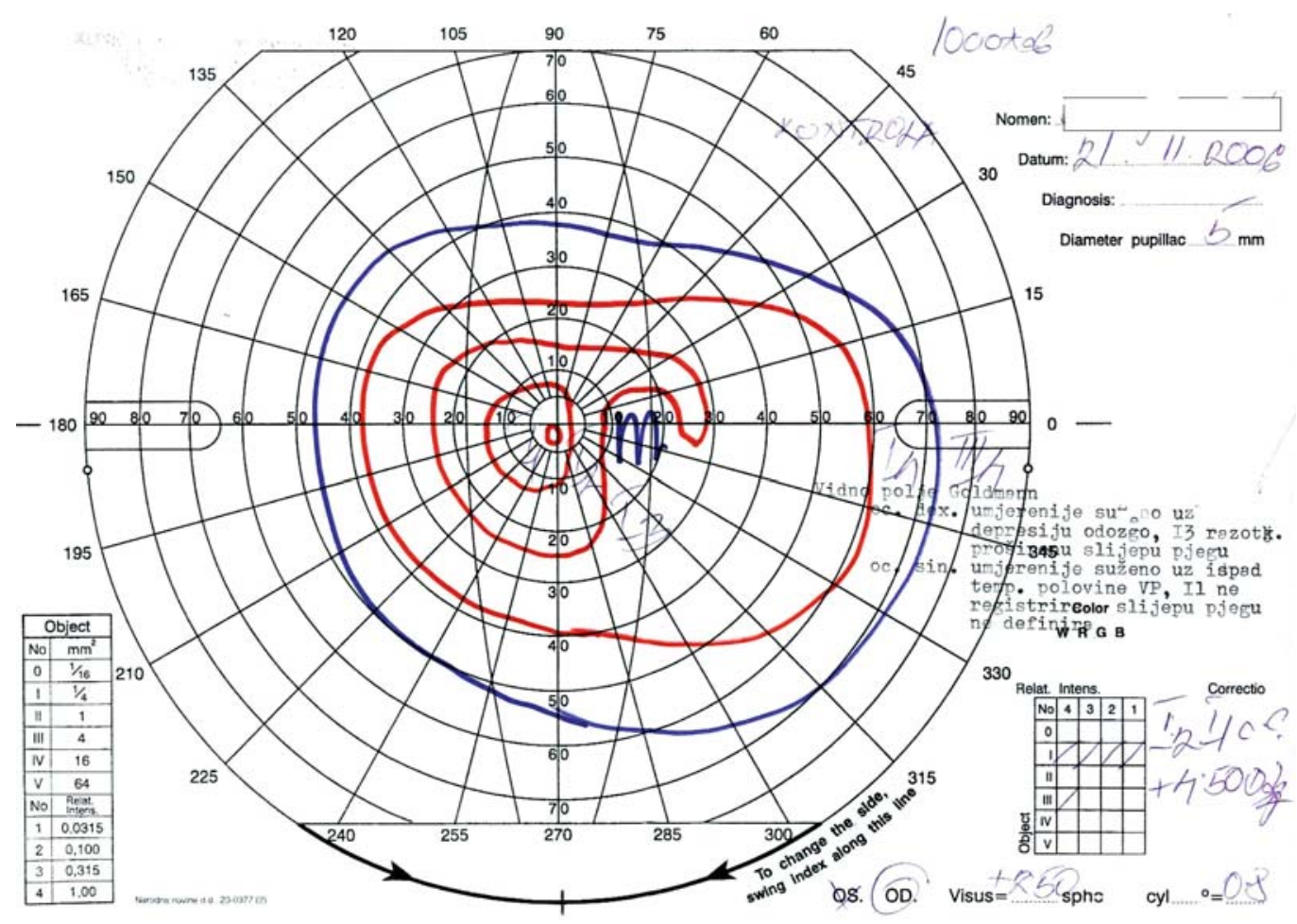

Figure 2a. Disturbances in visual function presented by Goldmann test, right eye.

til August 2006 the patient was treated with gemcitabin $600 \mathrm{mg} / \mathrm{m}^{2}$, days 1 and 8, every 28 days (purchased by the patient).

In August 2006 vision disturbances and headache had been first reported. Magnetic resonance imaging (MRI) showed tumour mass in supraselar region $30 \times 13 \mathrm{~mm}$ in diameter compressing optic chiasm. A radiological examination did not demonstrate other possible brain metastatic lesions. Based on the radiological imaging it was difficult to differentiate pituitary macroadenoma, meningeoma and metastasis of tumour (Figures 1a, 1b).

Since visual function deteriorated progressively, a trans-sphenoidal surgery was performed. Pathology and imunohistology revealed metastasis of clear cell renal carcinoma.
The visual function was quickly improved but Goldmann test (Figures 2a, 2b) showed still disturbances in the visual function. Endocrinological findings were almost consistent with panhypopituitarism: $\mathrm{T} 4=80.8$ $\mathrm{nml} / \mathrm{L}$ (normal range $70-165), \mathrm{TSH}<0.05$ $\mathrm{mIJ} / \mathrm{L}(0.40-4.2)$, testosteron $<0.03 \mathrm{nmol} / \mathrm{L}$ (3 - 22, for > $50 \mathrm{yrs})$, SHBG $7 \mathrm{nmol} / \mathrm{L}(15$ -100), cortisol = $13 \mathrm{nmol} / \mathrm{L}(138-690)$, aldosteron $=879 \mathrm{pmol} / \mathrm{L}(20-410)$. A replacement hormone therapy was introduced to the patient.

Postoperative control MRI after two months showed residual tumour $20 \times 13 \times 12$ $\mathrm{mm}$ in diameter but now along with multiple brain metastases. The palliative brain photon beam radiotherapy was performed, total dose $30 \mathrm{~Gy}$ in 10 fractions. CT scan of thorax and abdomen revealed the progression of the lung metastases and the occur- 


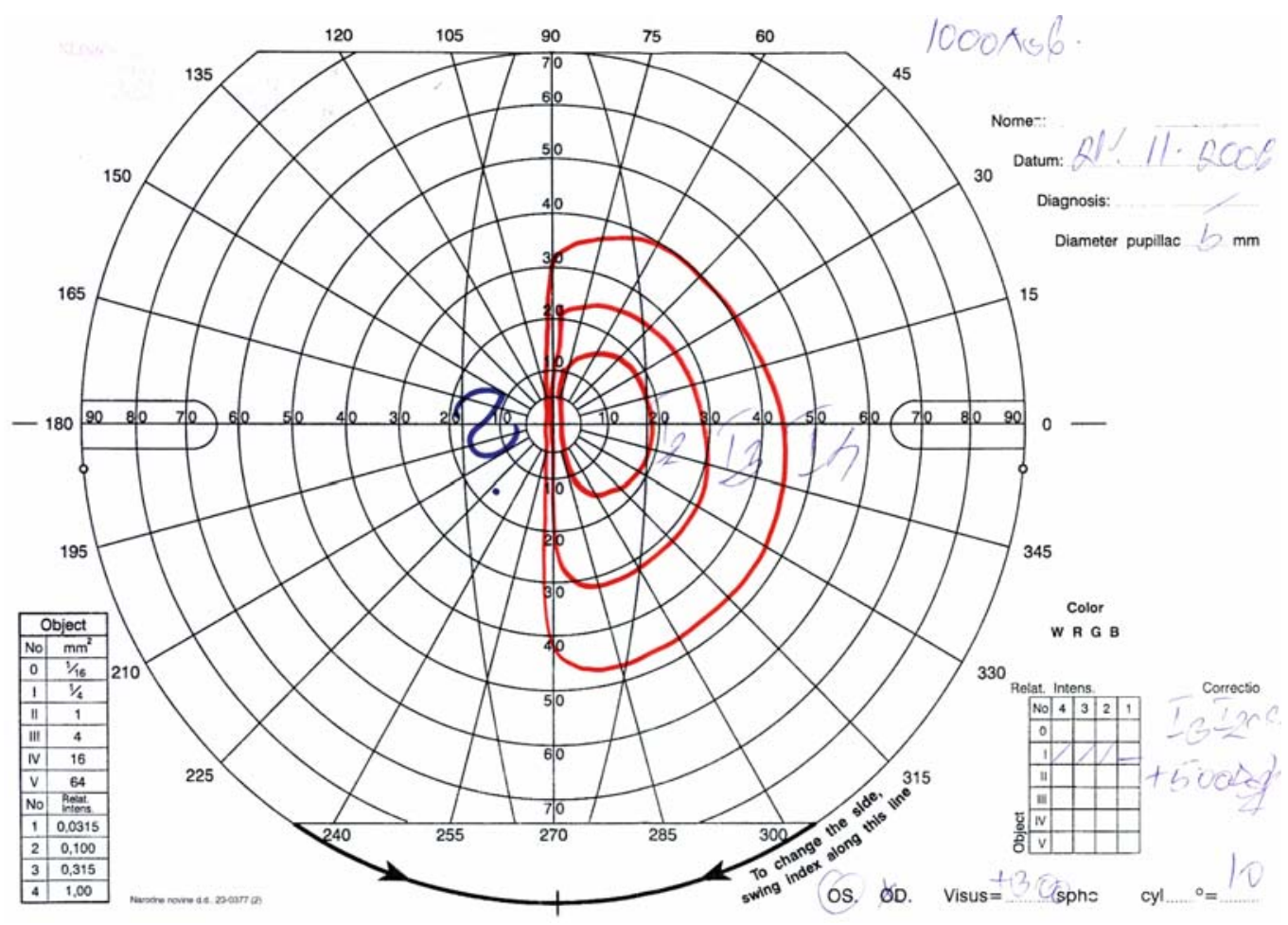

Figure $\mathbf{2 b}$. Disturbances in visual function presented by Goldmann test, left eye.

rence of new bone metastases. Surprisingly, the patient was without respiratory disturbances but he reported fatigue. His general appearance was Cushingoidal. He died ten months after the operation of the pituitary gland.

\section{Discussion}

Up to our knowledge only 24 cases of symptomatic pituitary metastasis of renal cell carcinoma has been reported in the literature (Table 1). Only six of them were female, while 18 were men. The majority i.e. 19 patients presented with hypopituitarism, while 17 patients presented with visual field defect like our patient. Our patient has not experienced symptoms of diabetes insipidus which is reported to be more frequent in pituitary metastasis than in pituitary adenomas. ${ }^{7,21}$ It is very difficult to differentiate pituitary metastasis from adenoma based on radiological and clinical findings. ${ }^{2,3,10,12,22}$ But Liu et al. ${ }^{7}$ found out that the strong enhancement of the tumour and the strong bone destruction without marked sellar enlargement are characteristic radiological features of pituitary metastasis. Fassett et al. ${ }^{2}$ stated that thickening of the pituitary stalk, invasion of the cavernous sinus and sclerosis of the surrounding sella turcica could indicate pituitary metastasis. Tumour invasiveness usually makes the resection difficult. There was no significant survival benefit in surgical series. ${ }^{2}$ The treatment of pituitary metastasis is multimodal, consisting of surgery, radiotherapy and chemotherapy. The long-term benefit of postoperative radiotherapy is not known 
due to the rarity of such cases. The applied dose ranged in the literature from 9 to 60 Gy, with median dose 36 Gy. ${ }^{6}$ Our patient was treated with $30 \mathrm{~Gy}$ in ten fractions due to the occurrence of brain metastases although first it was intended to apply a higher dose. Stereotactic radiotherapy can be beneficial in sparing the optic nerves. The primary aim of treating pituitary metastasis is to improve the quality of life through symptomatic relief and to prevent the neurological deterioration.

The overall median length of the patient's survival after the diagnosis of pituitary metastasis is only 180 days. ${ }^{6}$ However, the paper recently published by Gopan et al. ${ }^{20}$ reported the overall survival ranging from 6 to 46 months from the initial diagnosis of pituitary metastasis. This can be explained by the application of new chemotherapeutic agents like sorafenib and sunitinib. Stereotactic radiotherapy with or without whole brain radiotherapy was performed in all five reported patients.

In our case, whole brain radiotherapy was performed due to the brain dissemination. Sorafenib and sunitinib were not registered for the treatment of metastatic renal cell carcinoma in our country at the time.

Symptomatic pituitary metastasis of renal cell carcinoma is a rare case, occurring usually in highly disseminated renal cell carcinoma. Palliative surgery and radiotherapy treatment can contribute essentially to the improvement of the quality of life of such patients.

\section{References}

1 Yokoyama T, Yoshino A, Katayama Y, Watanabe T, Kashima Y, Yoshikawa T, et al. Metastatic pituitary tumour from renal cell carcinoma treated by fractionated stereotactic radiotherapy (Case report). Neurol Med Chir (Tokyo) 2004; 44: 47-52.

2 Fassett DR, Couldwell WT. Metastases to the pituitary gland. Neurosurg Focus 2004; 16: E8.
3 James RL Jr, Arsenis G, Stoler M, Nelson C, Baran D. Hypophyseal metastatic renal cell carcinoma and pituitary adenoma. Case report and review of the literature. Am J Med 1984; 76: 337-40.

4 Koshiyama H, Ohgaki K, Hida S, Takasu K, Yumitori K, Shimatsu A, Koh T. Metastatic renal cell carcinoma to the pituitary gland presenting with hypopituitarism. J Endocrinol Invest 1992; 15: 677-81.

5 McCormick PC, Post KD, Kandji AD, Hays AP. Metastatic carcinoma to the pituitary gland. $\mathrm{Br} J$ Neurosurg 1989; 3: 71-9.

6 Morita A, Meyer FB, Laws ER Jr. Symptomatic pituitary metastases. J Neurosurg 1998; 89: 69-73.

7 Liu H, Ymaki T, Oka S-I, Koyanagi I, Houkin K. Metastatic renal cell carcinoma mimicking pituitary adenoma: case report. Neurol Med Chir (Tokyo) 2005; 45: 418-22.

8 Anniko M, Lundquist PG, Silfversward C, Wersall J. Hypernephroma metastasis in the pituitary gland. A case report. Arch Otorhinolaryngol 1981; 232: 227-32.

9 Buonaguidi R, Ferdeghini M, Faggionato F, Tusini G. Intrasellar metastasis mimicking a pituitary adenoma. Surg Neurol 1983; 20: 373-8.

10 Eick JJ, Bell KA, Stephan MT, Fuselier HA Jr. Metastatic renal cell carcinoma presenting as an intrasellar mass on computerizes tomography. $J$ Urol 1985; 134: 128-30.

11 Horikoshi T, Mitsuka S, Kimura R, Fukamachi A, Nukui H. Renal cell carcinoma metastatic to the hypophysis, case report. Neurol Med Chir (Tokyo) 1988; 28: 78-82.

12 Nishio S, Tsukamoto H, Fukui M, Matsubara T: Hypophyseal metastatic hypernephroma mimicking a pituitary adenoma. Case report. Neurosurg Rev 1992; 15: 319-22.

13 Weiss RE, Corvalan AH, Dillon RW. Metastatic renal cell carcinoma presenting as impotence. J Urol 1993; 149: 821-2; discussion 823.

14 Uchino A, Hasuo K, Mizushima A, Matsumoto S, Mihara F, Jimi M et al. Intracranial metastasis of renal cell carcinoma: MR imaging. Radiat Med 1996; 14: 71-6.

15 Beckett DJ, Gama R, Wright J, Ferns GA. Renal carcinoma presenting with adrenocortical insufficiency due to a pituitary metastasis. Ann Clin Biochem 1998; 35(Pt 4): 542-4. 
16 Marar IE, Kandil H, Kanal E, Marion D, Inman M, Amico JA. Renal cell carcinoma metastatic to the pituitary gland: clinical manifestations and successful treatment with transsphenoidal resection. Endocr Pract 1998; 4: 204-7.

17 Weber J, Gassel AM, Hoch A, Spring A. Concomitant renal cell carcinoma with pituitary adenoma. Acta Neurochir (Wein) 2003; 145: 227-31.

18 Basaria S, Westra WH, Brem H, Salvatori R. Metastatic renal cell carcinoma to the pituitary presenting with hyperprolactinemia. J Endocrinol Invest 2004; 27: 471-4.

19 Pallud J, Nataf F, Roujeau T, Roux FX. Intraventricular haemorrhage from a renal cell carcinoma pituitary metastasis. Acta Neurochir (Wein) 2005; 147: 1003-4.

20 Gopan T, Toms SA, Prayson RA, Suh JH, Hamrahian AH, Weil RJ. Symptomatic pituitary metastases from renal cell carcinoma. Pituitary 2007; 10: 251-9.

21 Mäurer J, Busch M, Matthaei D, Helwig A, Dühmke E. Diabetes insipidus and breast carcinoma - the importance of NMR tomography planning. Strahelenther Onkol 1993; 169: 126-8.

22 Sioutos P, Yen V, Arbit E. Pituitary gland metastases. Ann Surg Oncol 1996; 3: 94-9. 